\title{
Prevalence of Internet Addiction among Young Adults in Kenya
}

\author{
Sandra Kimuge \\ Department of Psychiatry, University of Nairobi, Nairobi, Kenya \\ Email: Kimugesandra@gmail.com
}

How to cite this paper: Kimuge, S. (2021) Prevalence of Internet Addiction among Young Adults in Kenya. Open Access Library Journal, 8: e7864.

https://doi.org/10.4236/oalib.1107864

Received: August 18, 2021

Accepted: September 26, 2021

Published: September 29, 2021

Copyright $\odot 2021$ by author(s) and Open Access Library Inc.

This work is licensed under the Creative Commons Attribution International License (CC BY 4.0).

http://creativecommons.org/licenses/by/4.0/

\begin{abstract}
Background: Technology has a high influence on our lifestyle. This has a significant bearing on both the physical and mental health of an individual. Young adults spend a significant amount of time on the Internet. Studies have demonstrated that this overindulgence can be problematic. Internet addiction has an adverse effect on academic and occupational outcomes of Young people. Objectives: The objective of this study was to determine the prevalence of internet addiction among young adults in Kenya. Method: A cross-sectional quantitative study was carried out on young adults from one college in rural setting and one in urban setting. Two questionnaires were administered to the young adults. One was sociodemographic questionnaire and the second one was the Young's Internet Addiction Test. Results: The overall prevalence of internet addiction was (81.5\%). On analysis of the extent of severity of Internet use among young adults, it was found that majority of the young adults were moderate internet addicts (45.6\%) followed by mild internet addicts (31.2\%), normal internet users (18.5\%) and severe internet addicts (4.2\%). It was found that reported online activities significantly affect the levels of Internet use among young adults. Association was found between internet addiction and online betting, middle income and parental education as well as the course being taken in the college. Conclusion: Internet addiction both in rural and urban areas in Kenya is high and there is a need to start addressing the problem.
\end{abstract}

\section{Subject Areas}

Sociology

\section{Keywords}

Internet Addiction, Young Adult, Rural Site, Urban Site 


\section{Introduction}

Study by [1] stated that Use of information technologies has shown a very rapid growth for the last decade all over the world, increasing the number of people having personal computers, laptops or android phones. Easy access to the internet has changed the lives of people directly or indirectly affecting people's ideas, habits and behavior. Among other technology innovations, the internet use is spreading rapidly into daily life and people use internet for various purposes.

According to [2] internet is defined as a network of networks in which users at any one computer can, with permission get information from another device. It is a public, cooperative and self-sustaining facility accessible to hundreds of millions of people worldwide. It uses transmission control protocol. It has replaced old methods of communication such as postal services.

Report by [3] shows that internet became first available in Kenya in 1993 with its full accessibility being 1995 . In the year 2000, the population that used internet was $0.7 \%$ compared to $89.4 \%$ in the year 2017 . This is attributed to the internet being more accessible in universities, homes, schools libraries, public sites, and cyber cafes. This accessibility increases with the cheap prices and availability of the devices.

The term internet addiction was introduced by Young in the evolution of internet addiction, she proposed diagnostic criteria based on substance dependence criteria as stipulated in Diagnostic and Statistical Manual of Mental Disorders Fourth Edition [4]. She also mentioned the symptoms of internet addiction which include; obsessive thoughts about the internet, diminished impulse control, tolerance, inability to cease using the internet and withdrawal symptoms. These symptoms and comorbidity with other psychiatric disorders and social dysfunction are similar to those of substance use [5]. Findings by [6] showed that online activities or applications such as chat rooms and online games are important factors in determining internet addiction. Study by [7] on the nature of internet addiction on psychological factors in compulsive internet use in which he conducted on 17,000 people found out that approximately $5.9 \%$ met the criteria for an internet addiction diagnosis.

According to the International Telecommunication Union, about 3.2 billion people who are almost half of the world's population would be online. Of them, about 2 billion would be from developing countries, including 89 million from least developed countries. It defined Internet users as persons who had used any device to access the internet for the past 12 months. The statistics showed Africans using internet to have risen from $2 \%$ in 2005 to $25 \%$ in 2016 . Kenyan population that used the internet was $12,600,007$; this is $26 \%$ of the total population and was ranked number 43 worldwide [8].

Study by [9] postulated that $72 \%$ of young adults aged between $18-29$ years use social networking. He stated that majority of them use twitter in updating their status and reading other people's status updates and that two thirds of the 
young adults use wireless internet through laptops or cell phones. In the year 1996, he stated that internet addiction is the same as addiction to gambling, drugs and alcohol.

The use of internet has both positive and negative effects on a person. Some of the benefits include quick access to information, connecting youth from different geographically dispersed regions with new people, finding new friends and staying on with old friends, provides means of entertainment including online games, music, videos, movies and news and it also provide both national and international news [10]. Despite the positive impacts internet offers, there are negative impacts associated with its use which includes theft of Personal information, negative effects on family communication, virus threat which disrupts the normal functioning of the computer system and internet addiction [11].

The causes of internet addiction according to [12] include; brain makeup which is similar to those of substance dependency such as alcohol, structural changes to the prefrontal region of the brain, variable reinforcement effect of internet addiction (rewards), biological disposition depicted by deficient levels of dopamine and serotonin levels and to get relieve from anxiety and depression. It affects the pleasure center of the brain, personal relationships, work life, finances and school life. The internet addiction is also termed as online addiction, cyberspace addiction, internet addiction disorder, net addiction, pathological internet use and high internet dependency [13]. There are six components of internet addiction as stated by [14] which include; salience, mood modification, tolerance, withdrawal, conflict and relapse. In 2013 the American psychiatric association included internet gaming disorder in the appendix of diagnostic and statistical manual for mental disorders fifth edition as a condition that requires further research so that it can be added into the main manual [15].

The chairperson of the Kenya Counseling Association [16] in her article observed that internet addiction is rapidly increasing in Kenya. The problem, she said, was most prominent in young people aged between 18 and 28 years. She stated that the number of youths addicted to various internet sites surpasses that of those addicted to drugs and alcohol. She attributed this to the fact that most of the young adults are idle and the cost of accessing the internet is much lower than that of drugs and beer. She said that the bulk of internet addicts seeking rehabilitation complained of not being able to control their urge for seeking pornography, entertainment, and social sites such as Facebook, Twitter, Badoo and LinkedIn.

Internet addiction is categorized into five types as stated by [17] this includes; cybersex addiction involving online pornography and adult websites, computer addiction which involves using computer excessively for offline activities such as playing computer games, addiction to cyber relationship whereby an individual is addicted to all social networking such as Facebook and online dating services, information addiction whereby an individual spends a lot of time collecting and sifting web content without being able to control themselves and finally online 
compulsion which is characterized by uncontrollable thoughts to access online activities such as gaming repeatedly as an unconscious mechanism in order to avoid acceptable ideas and desires which by themselves arouse anxiety.

According to [18] the treatment strategies for internet addiction include the following; discovering the pattern of use and disrupting this patterns of internet use by suggesting new schedules, using external stoppers prompting to log off, setting goals in regard to the amount of time used, abstaining from a particular application that you are not able to control, using reminder cards for costs of internet addiction and benefits of breaking it, developing a personal inventory that shows all the activities you engaged in or cannot find the time due internet addiction, individual entering a support group which will compensate for lack of social support from the immediate family, engaging in family therapy to address relational problems and pharmacological interventions due to comorbidity with psychiatric disorders.

Study on internet addiction among college students in relation to their gender and locality at Rohtak district by [19] showed that as compared to the rural college students, internet addiction is more common among the urban college students and this was attributed to their ignorance [20]. Study on prevalence of internet addiction and associated factors found out that $2.1 \%$ of the studied population was at risk and 5.2\% were addicted users. They also found factors related to internet addiction such as being male, level of education, daily duration spent on using internet, most frequent time of internet use, monthly cost of use and tea consumption.

Studies related to internet addiction worldwide postulates that internet addiction is rapidly growing majorly among young adults aged between 18 - 28 years. The number of internet addicts surpasses those of substance addicts most probably because of the cheap cost of internet as compared to addictive substances. However there are no studies which have been carried out to confirm the same among Kenyan young adults.

\section{Literature Review}

The purpose of this study was to establish the prevalence of internet addiction among young adults in Kenya. Table 1 below shows previous scholarly work done on internet addiction among young adults globally.

\section{Methodology}

\subsection{Study Design}

This study used cross-sectional study design to describe the prevalence of internet addiction among young adults in Kenya.

\subsection{Study Area Description}

The study site was Tambach Teachers Training College in Elgeiyo Marakwet 
Table 1. Literature review.

\begin{tabular}{|c|c|c|c|}
\hline Study Title, Authors, Year & Study design/location & Sample size & Research findings \\
\hline $\begin{array}{l}\text { Relationships and associations between } \\
\text { videogame and internet addiction by } \\
\text { [21] }\end{array}$ & $\begin{array}{l}\text { Cross-sectional study } \\
\text { Eastern Turkey }\end{array}$ & 184 & $\begin{array}{l}-9.2 \% \text { internet addicts } \\
-42.9 \% \text { moderate internet addicts } \\
-15.5 \% \text { digital game addicted }\end{array}$ \\
\hline $\begin{array}{l}\text { Prevalence of Internet addiction } \\
\text { and its determinants by [22] }\end{array}$ & $\begin{array}{l}\text { Cross-sectional study } \\
\text { Western Maharashtra }\end{array}$ & 300 & $\begin{array}{l}\text {-Prevalence of internet addiction was } 58.87 \% \\
-7.45 \% \text { moderate addicts } \\
-51.42 \% \text { mild addicts }\end{array}$ \\
\hline $\begin{array}{l}\text { Description of internet addiction } \\
\text { among Chilean Medical Students } \\
\text { by [23] }\end{array}$ & $\begin{array}{l}\text { Cross-sectional study } \\
\text { Chile }\end{array}$ & 884 & $-11.5 \%$ Problematic internet users \\
\hline $\begin{array}{l}\text { Associations between internet addiction } \\
\text { symptoms ,disordered eating and body } \\
\text { image avoidance by [24] }\end{array}$ & $\begin{array}{l}\text { Cross-sectional study } \\
\text { France }\end{array}$ & 392 & $\begin{array}{l}-11 \% \text { male and } 9.7 \% \text { female were internet } \\
\text { addicts }\end{array}$ \\
\hline $\begin{array}{l}\text { Prevalence and risk factors of internet } \\
\text { addiction among students at English } \\
\text { University by [25] }\end{array}$ & $\begin{array}{l}\text { Cross-sectional study } \\
\text { East Midlands }\end{array}$ & 2257 & $\begin{array}{l}-3.2 \% \text { internet addicts which was associated } \\
\text { with combination of online gambling, } \\
\text { frequent online shopping, social online } \\
\text { activities, openness to experience, high } \\
\text { neuroticism, and low agreeableness }\end{array}$ \\
\hline $\begin{array}{l}\text { Prevalence of internet addiction and } \\
\text { its associated psychosocial and } \\
\text { psychological determinants by } \\
\text { [26] }\end{array}$ & $\begin{array}{l}\text { Cross-sectional study } \\
\text { Taiwan }\end{array}$ & $\begin{array}{l}1100 \text { and } 1360 \\
\text { respectively }\end{array}$ & $\begin{array}{l}-10.6 \% \text { and } 17.9 \% \text { internet addicts respectively } \\
\text {-Associated factors included being male, single, } \\
\text { student, life impairment due to internet use, } \\
\text { duration of internet use, online gaming, recent } \\
\text { and past suicide ideation/attempts }\end{array}$ \\
\hline $\begin{array}{l}\text { Prevalence of internet addiction } \\
\text { disorder by [27] }\end{array}$ & $\begin{array}{l}\text { Cross-sectional study } \\
\text { Italy }\end{array}$ & 2533 & $\begin{array}{l}-94.19 \% \text { normal internet users } \\
-5 \% \text { moderate internet addicts } \\
-0.79 \% \text { severe internet addicts }\end{array}$ \\
\hline $\begin{array}{l}\text { Factors influencing internet addiction } \\
\text { in a sample of freshmen university } \\
\text { students in China [28] }\end{array}$ & $\begin{array}{l}\text { Cross-sectional study } \\
\text { China }\end{array}$ & 3557 & $\begin{array}{l}-6.44 \% \text { internet addicts } \\
\text {-Risk factors include age of first exposure to } \\
\text { internet use, age of participant, residence }\end{array}$ \\
\hline $\begin{array}{l}\text { Prevalence of internet addiction } \\
\text { among medical students by [29] }\end{array}$ & $\begin{array}{l}\text { Cross-sectional study } \\
\text { Nigeria }\end{array}$ & 200 & $\begin{array}{l}-2.5 \% \text { severe internet addicts } \\
\text {-Those aged } 25-30 \text { years had severe } \\
\text { internet addiction }\end{array}$ \\
\hline $\begin{array}{l}\text { Effects of Betting in Kenyan } \\
\text { University by [30] }\end{array}$ & $\begin{array}{l}\text { Cross-sectional study } \\
\text { Kenya }\end{array}$ & 100 & $\begin{array}{l}-50 \% \text { bet once a week, } 28 \% \text { bet } \\
\text { Once a fortnight, } 12 \% \text { once a month. }\end{array}$ \\
\hline
\end{tabular}

County, in Rural Kenya. The other study site which is an urban setting was Kabete Technical University in Kiambu County.

\subsection{Sampling Method}

This study used stratified sampling to select the sample for the study on internet addiction among young adults in Kenya.

\subsection{Sample Size Determination and Formula Used}

The sample size was determined using Taro Yamane formula (1973) which was 
used in other similar studies. Sample size was 384 Participants.

\subsection{Data Collection Procedures}

After getting permission from the two Training Colleges, the Department of Psychiatry and Kenyatta National Hospital and University of Nairobi Ethics Research Committee (KNH/UON ERC), the researcher visited the training college and presented college site supervisor with the written approvals. The target population was informed about the study, its purpose, objectives and the benefits that will possibly come out from the study in the future. The researcher randomly selected participants from the sample frame starting from first years onwards until the sample size required was achieved. Participants who consented were enrolled to participate in the study the same day. Lecturers were kept away from the hall to prevent coercing of participants. The researcher was present while the participants were completing the questionnaires to offer any required assistance. The researcher later collected all filled questionnaires and thanked the participants. Data collection duration was two weeks.

\subsection{Variables}

The researcher used internet addiction disorder as the dependent variable, availability of internet and access to a device as the independent variables and moderating factors included age, gender, socio economic status, hobbies, course being studied and education level of the parents.

\subsection{Data Collection Instruments}

The researcher used structured questionnaire for the study which consisted of two sections completed by the participants. First part included researcher developed questionnaire comprised of age, gender, socioeconomic status, hobbies, course being studied and education level of parents.

The second section is the Internet Addiction Test by Young Kimberley in 1998. It is a 20 item scale that measures the presence and severity of self-reported compulsive use of internet among adolescents and adults. It was created by adapting DSM $1 \mathrm{~V}$ criteria for pathological gambling and it is a modification of earlier 8 item scale, Young's Internet Addiction Diagnostic Questionnaire. The internet addiction test views internet addiction as an impulse control disorder and the term internet refers to all types of online activities. It measures characteristics and behavior associated with compulsive use of internet and problems related to addictive use in personal, occupational and social functioning. Questions are randomized and each statement is weighted along a Likert scale continuum that ranges from $0=$ for less extreme behavior to $5=$ for most extreme behavior for each item. The tools maximum score is 100 points. The internet addiction total scores ranges with the higher the score representing the higher level of severity of internet compulsivity and addiction. Internet Addiction Test is a worldwide accepted and validated testing instrument. It is most widely used In- 
ternet addiction scale and the test has been translated in several languages including English, Chinese, French, Italian, Turkish, and Korean.

Pilot study of the study instrument was not done because [31] used the Internet Addiction Test in his study on relationship between depression and pathological internet use among university students in Kenya. He did a pilot study which pre-tested the research instrument to determine its reliability and validity. Chronbach's alpha for internet addiction test was 0.84 . Reliability of 0.8 and above indicates good reliability of instrument. The instrument is therefore reliable for use in the Kenyan population and hence will be adopted for this study.

Administration time is between 5 to 10 minutes to complete when self-administered.

\subsection{Data Analysis}

Collected data was inputted into the computer and analyzed using statistical package for social sciences (SPSS) version 20. Using descriptive statistics, socio demographics and scores from Internet Addiction Test (IAT) were presented. Socio demographic data was analyzed to give young adults characteristics such as age, gender, socio economic status, hobbies, course being studied and education level of the parents. Internet addiction test was analyzed to give the scores to show the presence and severity of self-reported internet addiction of the young adults. The results were presented in tables, figures, percentage and bar charts.

\section{Results}

\subsection{Sociodemographic Characteristics of the Study Participants}

The total number of the study participants was 384. Out of these, the female participants was 203 (52\%), while male were 181 (48\%). The ages of the sample ranged from 18 to 25 years with a mean age of 21.8 and standard deviation of 1.94.

The details of the socio demographic characteristics participants are given in Table 2 .

\subsection{Internet Use Classification}

According to Internet addiction test in appendix 30, internet use scores have been classified into four categories namely: normal level of Internet usage (0 30); mild level of Internet addiction (31 - 49); moderate level of internet addiction (50 - 79); and severe level of internet addiction (80 - 100). 45.6\% participants were moderate internet users. Detailed results are presented in the pie chart 1 in Figure 1.

\subsection{Internet Use in both Rural and Urban Settings}

The researcher went ahead and looked into differences in internet use in both rural and urban study areas a college in rural setting and a college in urban setting. The detailed findings on internet use by site are outlined in Figure 2. 
Table 2. Frequency distribution of socio demographic characteristics of the study participants.

\begin{tabular}{|c|c|c|c|}
\hline Characteristics & Classification & $\begin{array}{l}\text { Number of } \\
\text { participants }\end{array}$ & $\begin{array}{c}\text { Percentage } \\
(\%)\end{array}$ \\
\hline \multirow{4}{*}{ Age } & $18-19$ & 18 & 4.7 \\
\hline & $20-21$ & 43 & 11.2 \\
\hline & $22-23$ & 51 & 13.3 \\
\hline & $24-25$ & 69 & 18 \\
\hline \multirow{2}{*}{ Gender } & Male & 181 & 47.1 \\
\hline & Female & 203 & 52.9 \\
\hline \multirow{4}{*}{$\begin{array}{l}\text { Education level of } \\
\text { Father }\end{array}$} & University & 161 & 41.9 \\
\hline & Secondary school & 136 & 35.4 \\
\hline & Primary school & 60 & 15.6 \\
\hline & Nil education & 27 & 7.0 \\
\hline \multirow{4}{*}{$\begin{array}{l}\text { Education level of } \\
\text { Mother }\end{array}$} & University & 110 & 28.6 \\
\hline & Secondary school & 171 & 44.5 \\
\hline & Primary school & 71 & 18.5 \\
\hline & Nil education & 32 & 8.3 \\
\hline \multirow{3}{*}{ Course studied } & Education & 153 & 39.8 \\
\hline & Professional Courses & 129 & 33.6 \\
\hline & Craft courses & 102 & 26.6 \\
\hline \multirow{3}{*}{$\begin{array}{l}\text { Socio economic } \\
\text { status }\end{array}$} & High income-(Above 50,000 ) & 39 & 10.1 \\
\hline & Middle income $(21,000-50,000)$ & 188 & 49 \\
\hline & Low income $(0-20,000)$ & 157 & 40.9 \\
\hline \multirow{4}{*}{ Leisure activities } & Exercising & 244 & 63.5 \\
\hline & Reading & 209 & 54.4 \\
\hline & Listening to Music & 155 & 40.4 \\
\hline & Visiting Friends & 128 & 33.3 \\
\hline
\end{tabular}

\section{Prevalence of internet addiction}



Figure 1. Pie chart of internet use classification of the study participants.

\subsection{Reported Common Online Activities}

The findings on reported common online activities showed the following: web surfing/information (49.7\%); online betting/shopping (20.1\%), computer games (13.0\%), online relationships (9.6\%) and cybersex activity/ adult websites (7.6\%). 


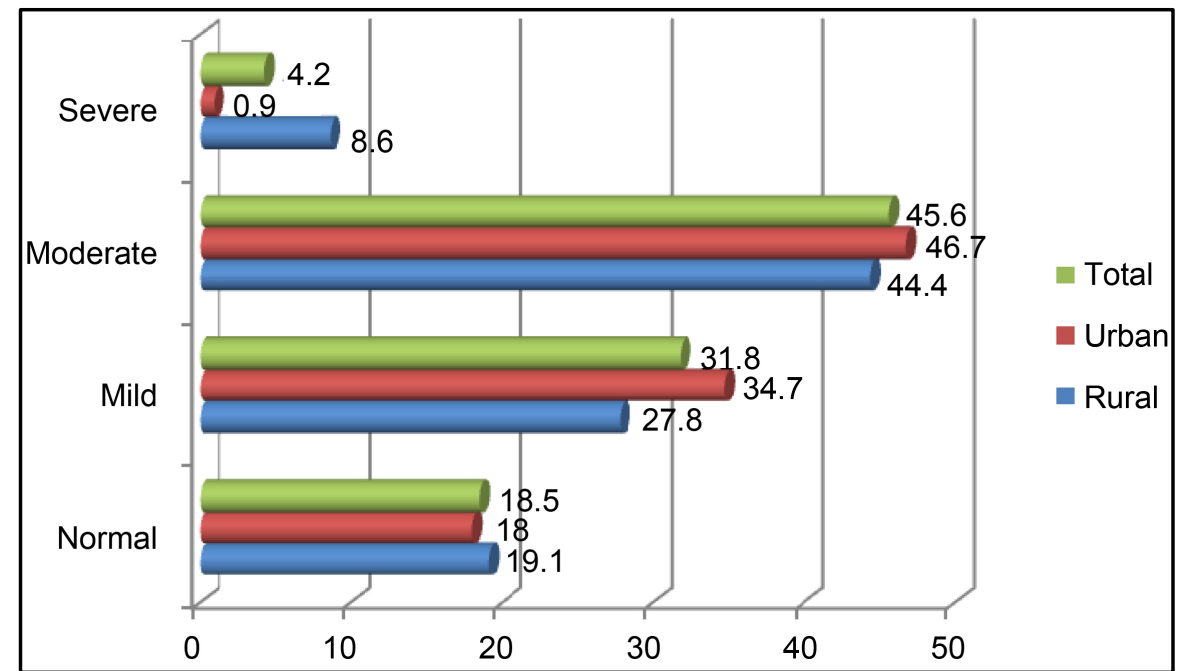

Figure 2. Severity of internet use in rural and urban setting.

The detailed findings on reported common online activities by site are outlined in Table 3. In Table 3 below $\mathrm{n}$ is the sample of one setting and $\mathrm{N}$ is the total sample from both settings.

\subsection{Association between Socio Demographic Factors and Internet Addiction}

The findings on reported activities Association between socio demographic factors and internet addiction by site are outlined in Table 4 below.

\section{Discussion}

\subsection{Prevalence of Internet Addiction}

This study was conducted to assess the prevalence of internet addiction among young adults in Kenya. A sample of 384 participants was used. The assessment was done based on Young's internet addiction scale. The overall prevalence of internet addiction was found to be $81.5 \%$. This was higher than studies done in majority of studies, for example a study done by [32] on Internet addiction, behavioral aspects, and health related problems associated with it among youth in Jabalpur district found the prevalence of internet addiction to be $74 \%$ and another study done in China by [33] showed a prevalence of $11.3 \%$ and by [34] in Chile found prevalence of $11.5 \%$.

The prevalence of severe internet addiction was found to be $4.2 \%$ which is higher percentage compared to other studies conducted among young adults. A study conducted by [35] in Nigeria reported a prevalence of severe addiction to be $2.5 \%$, similarly by [36] in Nepal (3.07\%) and [37] in Iran (2.8\%).

The prevalence of moderate internet addiction was $45.6 \%$ which is consistent with findings in other studies, for example a study which was done in Saudi Arabia by [38] showed a prevalence of $49.5 \%$.

Results on the severity of internet use showed that there were more participants 
Table 3. Frequency distribution of online activities in both rural and urban setting.

\begin{tabular}{|c|c|c|c|c|c|c|}
\hline \multirow{2}{*}{$\begin{array}{l}\text { Reported common } \\
\text { Online activities }\end{array}$} & Rural & Site & Urban & site & Total & \\
\hline & $\mathbf{n}$ & $\%$ & $\mathrm{n}$ & $\%$ & $\mathbf{N}$ & $\%$ \\
\hline Web surfing & 68 & 40.7 & 123 & 56.7 & 191 & 49.7 \\
\hline Online betting/shopping & 47 & 28.1 & 30 & 13.8 & 77 & 20.1 \\
\hline Online computer games & 18 & 10.8 & 32 & 14.7 & 50 & 13.0 \\
\hline Online relationship & 22 & 13.2 & 15 & 6.9 & 37 & 9.6 \\
\hline Adult websites & 12 & 7.2 & 17 & 7.8 & 29 & 7.6 \\
\hline
\end{tabular}

Table 4. Association between socio demographic factors and internet addiction.

\begin{tabular}{|c|c|c|c|c|c|c|c|c|c|c|}
\hline \multirow{3}{*}{ Mediators } & \multirow{3}{*}{ Classification } & \multirow{2}{*}{$\begin{array}{c}\text { Internet } \\
\text { Normal } \\
0-30\end{array}$} & \multirow[b]{2}{*}{ use } & \multirow{2}{*}{$\begin{array}{c}\text { use } \\
\text { Mild } \\
31-49\end{array}$} & \multirow[b]{2}{*}{ level } & \multicolumn{2}{|c|}{ levels } & \multirow[b]{2}{*}{$\begin{array}{l}\text { Severe } \\
80-100\end{array}$} & \multirow[b]{2}{*}{ Level } & \multirow{3}{*}{ P-Value } \\
\hline & & & & & & $\begin{array}{c}\text { Moderate } \\
50-79\end{array}$ & level & & & \\
\hline & & $\mathbf{n}$ & $\%$ & $\mathbf{n}$ & $\%$ & $\mathrm{n}$ & $\%$ & $\mathrm{n}$ & $\%$ & \\
\hline \multirow{4}{*}{ Age } & $18-19$ & 8 & 2.1 & 21 & 5.4 & 20 & 5.2 & 0 & 0 & \multirow{4}{*}{0.1577} \\
\hline & $20-21$ & 25 & 6.5 & 46 & 12 & 57 & 14.8 & 2 & 0.5 & \\
\hline & $22-23$ & 20 & 5.2 & 26 & 6.8 & 49 & 12.8 & 5 & 1.3 & \\
\hline & $24-25$ & 18 & 4.5 & 29 & 7.6 & 49 & 12.8 & 9 & 2.3 & \\
\hline \multirow{2}{*}{ Gender } & M & 30 & 7.8 & 51 & 13.3 & 88 & 39.1 & 12 & 3.1 & \multirow{2}{*}{0.1577} \\
\hline & $\mathrm{F}$ & 41 & 10.7 & 71 & 18.5 & 87 & 22.7 & 4 & 1.0 & \\
\hline \multirow{4}{*}{$\begin{array}{l}\text { Education } \\
\text { level of father }\end{array}$} & University & 25 & 6.5 & 48 & 12.5 & 86 & 22.4 & 2 & 0.5 & \multirow{4}{*}{0.3260} \\
\hline & Secondary & 31 & 8.1 & 43 & 11.2 & 54 & 14.1 & 8 & 2.1 & \\
\hline & Primary & 12 & 3.1 & 21 & 5.5 & 22 & 5.7 & 5 & 1.3 & \\
\hline & Nil & 3 & 0.8 & 9 & 2.3 & 14 & 3.6 & 1 & 0.3 & \\
\hline \multirow{4}{*}{$\begin{array}{l}\text { Education } \\
\text { level of } \\
\text { mother }\end{array}$} & University & 16 & 4.2 & 38 & 9.9 & 54 & 14.1 & 2 & 0.5 & \multirow{4}{*}{0.8154} \\
\hline & Secondary & 34 & 8.9 & 50 & 13.0 & 78 & 20.3 & 9 & 2.3 & \\
\hline & Primary & 16 & 4.2 & 21 & 5.5 & 29 & 7.6 & 5 & 1.3 & \\
\hline & Nil & 5 & 1.3 & 14 & 3.6 & 13 & 3.4 & 0 & 0 & \\
\hline \multirow{3}{*}{$\begin{array}{l}\text { Socio } \\
\text { economic } \\
\text { status }\end{array}$} & Low & 37 & 9.6 & 47 & 12.2 & 67 & 17.4 & 6 & 1.6 & \multirow{3}{*}{0.6763} \\
\hline & Middle & 26 & 6.8 & 65 & 16.9 & 88 & 22.9 & 9 & 2.3 & \\
\hline & High & 7 & 2.1 & 12 & 3.1 & 19 & 4.9 & 1 & 0.3 & \\
\hline \multirow{3}{*}{$\begin{array}{l}\text { Course } \\
\text { studied }\end{array}$} & $\mathrm{P} 1$ & 31 & 8.1 & 44 & 11.5 & 64 & 16.7 & 14 & 3.6 & \multirow{3}{*}{0.2274} \\
\hline & Professional technical & 18 & 4.7 & 75 & 19.5 & 36 & 9.4 & 0 & 0 & \\
\hline & Craft technical & 15 & 3.9 & 37 & 9.6 & 48 & 12.5 & 2 & 0.5 & \\
\hline \multirow{4}{*}{$\begin{array}{l}\text { Leisure } \\
\text { Activities }\end{array}$} & Exercising & 47 & 12.2 & 82 & 21.4 & 107 & 27.9 & 8 & 2.1 & \multirow{4}{*}{0.238} \\
\hline & Reading & 41 & 10.7 & 72 & 18.6 & 93 & 24.2 & 3 & 0.8 & \\
\hline & Music & 23 & 6 & 55 & 14.3 & 70 & 18.2 & 7 & 1.8 & \\
\hline & Friends & 29 & 7.6 & 37 & 9.6 & 55 & 14.3 & 7 & 1.8 & \\
\hline \multirow{5}{*}{$\begin{array}{l}\text { Online } \\
\text { activities }\end{array}$} & Web surfing & 42 & 10.9 & 70 & 18.2 & 79 & 20.6 & 0 & 0 & \multirow{5}{*}{0.0105} \\
\hline & Online betting/shopping & 13 & 3.4 & 22 & 5.7 & 31 & 8.1 & 11 & 2.9 & \\
\hline & Online computer games & 9 & 2.3 & 18 & 4.7 & 22 & 5.7 & 1 & 0.3 & \\
\hline & Online relationship & 3 & 0.8 & 5 & 1.3 & 26 & 6.8 & 3 & 0.8 & \\
\hline & Adult website & 3 & 0.8 & 9 & 2.3 & 16 & 4.2 & 1 & 0.3 & \\
\hline
\end{tabular}

from rural setting with normal use and severe internet addiction than those in the urban setting, however there were more participants with mild and moderate 
internet addiction in urban setting than those in rural setting. Severe internet addiction in rural and urban settings was as follows; rural male (13.9\%), rural female $(4.45 \%)$, urban male $(1.8 \%)$ and urban female $(0 \%)$. This is consistent with [39] study in Japan which showed that living in rural area was a risk factor to internet addiction.

\subsection{Reported Online Activities}

There was a significant association between reported online activities and internet addiction. For those participants with moderate internet addiction, web surfing had majority participants (20.6\%), and adult website the least with $4.2 \%$ of the participants. For mild internet users, web surfing had majority participants (18.2\%) and the least being online relationship (1.3\%). For normal users web surfing had majority participants (10.9\%) while online relationships and adult websites had the least participants $(0.8 \%)$.

This findings on reported online activities are consistent with other studies such as; study done in Taiwan by [40] showed that online activities are important predictors of youth initiation and of the persistence of Internet addiction; study by [41] and [42] indicated that online activities including e-mail and information search, as well as shopping, chatting, online communities, games and sex were domains of young adults, mostly male adults. They also reported that online activities were preceded by negative consequence of internet use, especially neglect of recreational activities and problems with family/partner, work or education, health, Sleep deprivation, failure to exercise and to engage in faceto-face social activities, negative affective states, and decreased ability to concentrate. Another study by [43] in Poland and by [44] in Mauritius reported that participants searching information online had severe internet addiction.

Regarding online relationships study by [45] and by [46] indicated that internet use is predominantly used for social purposes, mostly related to the maintenance of established offline networks. Extraverts appear to use social networking sites for social enhancement, whereas introverts use it for social compensation, each of which appears to be related to greater internet usage. The study revealed that effects between Internet addiction and approaches to friendship may be reciprocal. Being oriented toward having more online friends, preferring online communication, and spending more time online were related to increased risk of Internet addiction.

Regarding online betting activities, study by [47] showed that with the expansion of the gambling industry in sub-Saharan countries gambling activities are on the rise; this can be due to the high unemployment rate of youth and low wages among the employed ones.

\subsection{Association between Socio-Demographic Factors and Internet Addiction}

Regarding age of the participants, the findings of the study revealed that there 
was no significant association between age and internet addiction. Participants aged between 22 - 23 years recorded highest frequency of all levels of internet addiction while those aged between 24 - 25 years recorded the lowest frequency with $2.3 \%$ participants having severe internet addiction. Respondents aged between 20 - 21 years findings showed that majority were normal internet users. Participants aged between 18 - 19 years did not have severe internet addiction and reported a low frequency of $5.2 \%$ in moderate internet addiction. Study by [48] found that age played a role in determining the level of internet addiction.

There was no significant association between gender and internet addiction. Male gender was found to be having a higher frequency in severe internet addiction at $3.1 \%$ compared to their female counterparts who had $1.0 \%$. The frequency for Moderate internet addicts was male (39.1\%) and female (22.7\%). The frequency of female with mild internet addiction was $18.5 \%$. This is consistent with studies by [49] who found that internet addiction was higher in male than female. In Kenyan setting this could be associated with men risk taking behaviour as they look for more money through betting and also house chores is left to women so men have a lot of idle time for their online activities.

Regarding the level of education of the participants' parents and internet addiction, there was no significant association. Participants whose fathers had secondary level of education had a frequency of $2.1 \%$ in severe of internet addiction, while those with nil education had the lowest frequency at $0.8 \%$. Secondary and primary level of education was seen as the most influencing factors to internet addiction while university and nil education had low influence. However for moderate addicts (22.4\%) and mild addicts (12.5\%), University level of education had the greatest influence. Mothers with secondary level education had a frequency of $2.3 \%$ on severe internet addiction followed by those with primary education (1.35). Nil education (0\%) and university level (0.5\%) acted as protective factor for severe internet addiction. This is consistent with [50] study which significant association between addictive internet use and parental education. Another study by [51] indicated that fathers and mothers who had negative views of the Internet, tended to encourage less their children to engage in online activities and worried more for the possibility that their child is addicted to computer use; their worries weren't correlated with their children's results.

The findings showed no association between socio economic status and internet addiction. Results on Socio economic status showed that those from middle income families $(2.3 \%)$ had the highest influence on severe internet addiction followed by those from low income families (1.6\%) and those from high income families $(0.3 \%)$ had the least influence. For normal internet users being from a low income family $(9.6 \%)$ acted as a protective factor. This contrasts the findings of [52] study in Taiwan and by [53] in Korea which showed those from low income families having highest severity of internet addiction. This they attributed to lack of supervision by parents from poor backgrounds.

There was no significant association between courses studied and internet ad- 
diction. Young adults studying P1 course reported a (3.6\%) frequency on severe internet addiction, followed by those studying craft courses (0.5\%) while those doing professional courses had no severe addiction. Those doing P1 course had (16.7\%) participants with moderate internet addiction and lowest frequency recorded by those doing professional technical course (9.4\%). Those studying professional technical courses recorded a frequency of (19.5\%) in mild internet addiction, while those doing craft technical course had a frequency of (9.6\%). (8.1\%) P1 participants were normal internet users and craft technical participants were the least (3.9\%). This study found that the type of course and individual engages in predisposes one to internet addiction. However it was difficult to establish if the frequency of P1 course was high due to being in a rural setting or because of the course itself.

There was no significant association between frequent leisure activities and internet addiction. Regarding the four frequent leisure activities, the following was found; majority of participants reported engaging in exercising (63.5\%); reading novels, bible and magazines (53.1\%), listening to music (40.4\%) and spending time with friends (33.3\%). Other activities reported included; watching television/movies (31.3\%), dancing (31.3\%), swimming (28.4\%), going to church (4.2\%), alcohol use (5.5\%), sleeping (2.6\%), sexual activities (0.8\%) and eating (3.9\%). There was a positive correlation between alcohol use (5.5\%) and severe internet addiction (0.044). This is consistent with findings by [54] report that outdoor activities decrease chances of internet addiction. According to study by [55], 19.6\% Chinese citizens reported internet use as leisure time activity. Regarding time spent on Internet use in leisure time, more than $96 \%$ reported going online in non-work situations and Severe Internet addicts were equally more active in leisure time activities.

Researcher went ahead and looked into the association between number of years online and internet addiction and found the $\mathrm{P}$ value $=0.000$, hence a statistically significant difference in the mean internet addiction between the various ages of the independent variable. Looking at the results there is a statistically significant difference between those who had been online users between 0-8 years and those over 9 years.

\subsection{Conclusion}

The current study showed that access to internet use is high among young adults in Kenya both in rural and urban settings. There is a high prevalence of internet addiction among young adults in Kenya compared to findings of studies done in other countries. Web surfing is the most common online activity carried out by participants both in urban and rural areas. Active measures such as carrying out public awareness campaign and more research among other age groups should be taken into account by the various stakeholders. The study was done among college going students hence the findings might not be generalized to the non-college population. 


\section{Acknowledgements}

Thank you to my supervisors Dr. Muthoni Mathai and Dr. Judy Kamau whose guidance and insights were invaluable in the completion of this work, all participants who participated in the study, my entire family for the support they give me throughout the period of my dissertation and my immediate employer and my colleagues at work for allowing me to pursue this study.

\section{Conflicts of Interest}

The author declares no conflicts of interest.

\section{References}

[1] Ruzgar, N.S. (2005) A Research on the Purpose of Internet Usage and Learning via Internet. The Turkish Online Journal of Educational Technology, 4, 27-32.

[2] WhatIs.com, from TechTarget; ed. by Margaret Rouse and Ivy Wigmore et al. Internet Resource. http://whatis.techtarget.com

[3] https:/itu.int/en/ITU-D/Statistics/Pages/stat/default.aspx

[4] Young, K.S. (2017) Assessment Issues with Internet-Addicted Children and Adolescents. In Young, K.S. and de Abreu, C.N., Eds., Internet Addiction in Children and Adolescents. Risk Factors, Assessment, and Treatment. Springer Publishing Company, New York, 143-160. https://doi.org/10.1891/9780826133731.0008

[5] Beard, K.W. and Wolf, E.M. (2001) Modification in the Proposed Diagnosis Criteria for Internet Addiction. CyberPsychology and Behavior, 4, 377-383.

https://doi.org/10.1089/109493101300210286

[6] Young, K.S. (1998) Internet Addiction: The Emergence of a New Clinical Disorder. CyberPsychology \& Behavior, 1, 237-244. https://doi.org/10.1089/cpb.1998.1.237

[7] Greenfield, D. (2012) The Addictive Properties of Internet Usage. Internet Addiction: A Handbook and Guide to Evaluation and Treatment. 135-153. https://doi.org/10.1002/9781118013991.ch8

[8] https://news.itu.int/itu-releases-2017-global-information-and-communication-tech nology-facts-and-figures

[9] Young, K. (2015) The Evolution of Internet Addiction Disorder. In Montag, C. and Reuter, M., Eds., Internet Addiction: Neuroscientific Approaches and Therapeutical Interventions, Springer Science + Business Media, Berlin, 3-17. https://doi.org/10.1007/978-3-319-07242-5_1

[10] Barrie, J. and Presti, D. (1996) The World Wide Web as an Instructional Tool. Science, 274, 371-372. https://doi.org/10.1126/science.274.5286.371

[11] Young, K.S. (1996) Internet Addiction: The Emergence of a New Clinical Disorder. CyberPsychology \& Behavior, 1, 237-244.

http://www.netaddiction.com/articles/newdisorder.pdf https://doi.org/10.1089/cpb.1998.1.237

[12] Dalal, P.K. and Basu, D. (2016) New Yorker Magazine. Just Click No. Talk Story about Dr. Ivan K. Goldberg and the Internet Addiction Disorder.

[13] Davis, R.A., Flett, G.L. and Besser, A. (2002) Validation of a New Scale for Measuring Problematic Internet Use: Implications for Pre-Employment Screening. CyberPsychology \& Behavior, 5, 331-345. https://doi.org/10.1089/109493102760275581

[14] Griffiths, M. (2009) Internet Addiction-Time to Be Taken Seriously? Addiction Re- 
search, 8, 413-418. https://doi.org/10.3109/16066350009005587

[15] American Psychiatric Association (2013) Diagnostic and Statistical Manual of Mental Disorders. 5th Edition, American Psychiatric Association, Washington DC. https://doi.org/10.1176/appi.books.9780890425596

[16] http://africa.comworldseries.com/

[17] Young, K.S. (1999) Internet Addiction: Symptoms, Evaluation, and Treatment Innovations in Clinical Practice (Vol. 17). In: VandeCreek, L. and Jackson, T.L., Eds., Innovations in Clinical Practice: A Source Book, Professional Resource Press, Sarasota, 19-31.

[18] Young, K.S. and de Abreu, C.N. (2011) Internet Addiction: A Handbook and Guide to Evaluation and Treatment. John Wiley \& Sons, Inc., Hoboken.

[19] Hooda, M. (2014) Influence of Internet Addiction on the Mental Health of Adolescents. GALAXY International Interdisciplinary Research Journal GIIRJ, 2, 51.

[20] Salehi, M., Khalili, M., Hojjat, S., Salehi, M. and Danesh, A. (2014) Prevalence of Internet Addiction and Associated Factors among Medical Students from Mashhad, Iran in 2013. International Journal of the Iranian Red Crescent Society, 16, e17256. https://doi.org/10.5812/ircmj.17256

[21] Gunuc, S. (2015) Relationships and Associations between Video Game and Internet Addictions: Is Tolerance a Symptom Seen in All Conditions. Computers in Human Behavior, 49, 517-525. https://doi.org/10.1016/j.chb.2015.03.063

[22] Chaudhari, B., Menon, P., Saldanha, D., Tewari, A. and Bhattacharya, L. (2015) Internet Addiction and Its Determinants among Medical Students. Industrial Psychiatry Journal, 24, 158-162. https://doi.org/10.4103/0972-6748.181729

[23] Berner, J.E., Santander, J., Contreras, A.M. and Gómez, T. (2014) Description of Internet Addiction among Chilean Medical Students: A Cross-Sectional Study. Academic Psychiatry, 38, 11-14. https://doi.org/10.1007/s40596-013-0022-6

[24] Rodgers, R.F., Melioli, T., Laconi, S., Bui, E. and Chabrol, H. (2013) Internet Addiction Symptoms, Disordered Eating, and Body Image Avoidance. Cyberpsychology, Behavior, and Social Networking, 16, 56-60. https://doi.org/10.1089/cyber.2012.1570

[25] Kuss, D.J., Griffiths, M.D. and Binder, J.F. (2013) Internet Addiction in Students: Prevalence and Risk Factors. Computers in Human Behavior, 29, 959-966.

https://doi.org/10.1016/j.chb.2012.12.024

[26] Leung \& Lee (2012) The Influences of Information Literacy, Internet Addiction and Parenting Styles on Internet Risks. New Media and Society, 14, 117-136. https://doi.org/10.1177/1461444811410406

[27] Tsai, H., Cheng, S., Yeh, T.L., Shih, C.-C., Chen, K., Yang, Y.-C. and Yang, Y. (2009) The Risk Factors of Internet Addiction-A Survey of University Freshmen. Psychiatry Research, 167, 294-299. https://doi.org/10.1016/j.psychres.2008.01.015

[28] Poli, R. and Agrimi, E. (2012) Internet Addiction Disorder: Prevalence in an Italian Student Population. Nordic Journal of Psychiatry, 66, 55-59.

https://doi.org/10.3109/08039488.2011.605169

[29] Ni, X., Yan, H., Chen, S. and Liu, Z. (2009) Factors Influencing Internet Addiction in a Sample of Freshmen University Students in China. Cyberpsychology \& Behavior, 12, 327-330. https://doi.org/10.1089/cpb.2008.0321

[30] Wankwo, C.N. (2015) Prevalence of Internet Addiction among Medical Students in Abia State University, Uturu, Nigeria. Abia State University Medical Students' Journal, 10, 33-39. 
[31] Koross, R. (2016) University Students Gambling: Examining the Effects of Betting on Kenyan University Students' Behavior. International Journal of Liberal Arts and Social Science, 4, 57-64.

[32] Maroma Fabio Ogach (2015) Relationship between Depression and Pathological Internet Use among University Students in Kenya.

http://ir-library.ku.ac.ke/handle/123456789/14428

[33] Thakur, A., Peepre, K., Vaswani, A., Gupta, K., Verma, A., Singh, D. and Kasar, P. (2017) Internet Addiction, Behavioural Aspects, and Health Related Problems Associated with It: A Cross Sectional Study among Engineering Students of Jabalpur District. International Journal of Research in Medical Sciences, 6. 253. https://doi.org/10.18203/2320-6012.ijrms20175729

[34] Lu, L., Xu, D.D., Chai, J.-X., Wang, D., Li, L., Zhang, L., Lu, L., Ng, C., Ungvari, G., Mei, S.-L. and Xiang, Y.-T. (2018) Prevalence of Internet Addiction Disorder in Chinese University Students: A Comprehensive Meta-Analysis of Observational Studies. Journal of Behavioral Addictions, 7, 1-14. https://doi.org/10.1556/2006.7.2018.53

[35] Berner, J.E., Santander, J., Contreras, S.A. and Gómez, T. (2014) Description of Internet Addiction among Chilean Medical Students: A Cross-Sectional Study. Academic Psychiatry, 38, 11-14. https://doi.org/10.1007/s40596-013-0022-6

[36] Chinatu-Nwankwo, O. (2015) Prevalence of Internet Addiction among Medical Students in Abia State University, Uturu, Nigeria.

[37] Pramanik, T., Sherpa, M.T. and Shrestha, R. (2012) Internet Addiction in a Group of Medical Students: A Cross Sectional Study. Nepal Medical College Journal, 14, 46-48.

[38] Ghamari, F., Mohammadbeigi, A., Mohammadsalehi, N. and Hashiani, A.A. (2011) Internet Addiction and Modeling Its Risk Factors in Medical Students, Iran. Indian Journal of Psychological Medicine, 33, 158-162. https://doi.org/10.4103/0253-7176.92068

[39] Abdel-Salam, D.M., Alrowaili, H.I., Albedaiwi, H.K., et al. (2019) Prevalence of Internet Addiction and Its Associated Factors among Female Students at Jouf University, Saudi Arabia. Journal of the Egyptian Public Health Association, 94, 12. https://doi.org/10.1186/s42506-019-0009-6

[40] Ko, C.-H., Yen, J.-Y., Chang, Y.-P. and Cheng, C.-P. (2009) Multi-Dimensional Discriminative Factors for Internet Addiction among Adolescents Regarding Gender and Age: Internet Addiction in Adolescence. Psychiatry and Clinical Neurosciences, 63, 357-364. https://doi.org/10.1111/j.1440-1819.2009.01969.x

[41] Chang, F.C., Chiu, C.H., Miao, N.F., Chen, P.H., Lee, C.M., Chiang, J.T. and Pan, Y.C. (2015) The Relationship between Parental Mediation and Internet Addiction among Adolescents, and the Association with Cyberbullying and Depression. Comprehensive Psychiatry, 57, 21-28. https://doi.org/10.1016/j.comppsych.2014.11.013

[42] Müller, K.W., Koch, A., Dickenhorst, U., Beutel, M.E., Duven, E. and Wölfling, K. (2013) Addressing the Question of Disorder-Specific Risk Factors of Internet Addiction: A Comparison of Personality Traits in Patients with Addictive Behaviors and Comorbid Internet Addiction. BioMed Research International, 2013, Article ID: 546342. https://doi.org/10.1155/2013/546342

[43] Li, W., O’Brien, J.E., Snyder, S.M. and Howard, M.O. (2015) Characteristics of Internet Addiction/pathological Internet Use in U.S. University Students: A Qualitative-Method Investigation. PLOS ONE, 10, e 0117372.

https://doi.org/10.1371/journal.pone.0117372 
[44] Pawłowska, B., Zygo, M., Potembska, E., Kapka-Skrzypczak, L., Dreher, P. and Kędzierski, Z. (2015) Prevalence of Internet Addiction and Risk of Developing Addiction as Exemplified by a Group of Polish Adolescents from Urban and Rural Areas. Annals of Agricultural and Environmental Medicine, 22, 129-136. https://doi.org/10.5604/12321966.1141382

[45] Goorah, S. and Azhar, F. (2018) Prevalence and Characteristics of Internet Addiction among University Students in Mauritius.

[46] Kuss, D.J. and Griffiths, M.D. (2011) Online Social Networking and Addiction-A Review of the Psychological Literature. International Journal of Environmental Research and Public Health, 8, 3528-3552. https://doi.org/10.3390/ijerph8093528

[47] Smahel, D., Helsper, E., Green, L., Kalmus, V., Blinka, L. and Ólafsson, K. (2012) Excessive Internet Use among European Children. EU Kids Online. https://doi.org/10.1332/policypress/9781847428837.003.0015

[48] Ssewanyana, D. and Bitanihirwe, B. (2018) Problem Gambling among Young People in Sub-Saharan Africa. Frontiers in Public Health, 6, 23. https://doi.org/10.3389/fpubh.2018.00023

[49] Xin, M., et al. (2017) Online Activities, Prevalence of Internet Addiction and Risk Factors Related to Family and School among Adolescents in China. Addictive Behaviors Reports, 7, 14-18. https://doi.org/10.1016/j.abrep.2017.10.003

[50] Heo, J., Oh, J., Subramanian, S.V., Kim, Y. and Kawachi, I. (2014) Addictive Internet Use among Korean Adolescents: A National Survey. PLoS ONE, 9, e87819. https://doi.org/10.1371/journal.pone.0087819

[51] Siomos, K., Floros, G., Fisoun, V., Evaggelia, D., Farkonas, N., Sergentani, E., Lamprou, M. and Geroukalis, D. (2012) Evolution of Internet Addiction in Greek Adolescent Students over a Two-Year Period: The Impact of Parental Bonding. European Child \& Adolescent Psychiatry, 21, 211-219. https://doi.org/10.1007/s00787-012-0254-0

[52] Yen, J.Y., Yen, C.F., Chen, C.C., Chen, S.H. and Ko, C.H. (2007) Family Factors of Internet Addiction and Substance Use Experience in Taiwanese Adolescents. $C y$ berPsychology \& Behavior, 10, 323-329. https://doi.org/10.1089/cpb.2006.9948

[53] Lee, C.-S. and McKenzie, K. (2015) Socioeconomic and Geographic Inequalities of Internet Addiction in Korean Adolescents. Psychiatry Investigation, 12, 559-562. https://doi.org/10.4306/pi.2015.12.4.559

[54] Lin, C.H., Lin, S.L. and Wu, C.P. (2009) The Effects of Parental Monitoring and Leisure Boredom on Adolescents' Internet Addiction. Adolescence, 44, 993-1004.

[55] Zhou, Z.H., Zhu, H.M., Li, C. and Wang, J. (2014) Internet Addictive Individuals Share Impulsivity and Executive Dysfunction with Alcohol-Dependent Patients. Frontiers in Behavioral Neuroscience, 8, 288. https://doi.org/10.3389/fnbeh.2014.00288 